\title{
DYNAMIC CAPITAL STRUCTURE DETERMINANTS: SOME EVIDENCE FROM SOUTH AFRICAN FIRMS
}

\author{
Vusani Moyo* \\ University of Pretoria \\ vusanimoyo20@hotmail.com \\ Hendrik Wolmarans" \\ University of Pretoria \\ Leon Brümmer+ \\ University of Pretoria \\ hendrik.wolmarans@up.ac.za \\ leon.brummer@up.ac.za
}

Received: November 2012

Accepted: July 2013

\begin{abstract}
This study uses a sample of 49 manufacturing, 24 mining and 23 retail firms listed on the Johannesburg Stock Exchange during the period 2005-2010 to investigate the relationship between leverage and the firm's key financial performance variables. Leverage is directly proportional to cash flow. This is consistent with the trade-off (TO) and agency theories. Capital expenditure is positively correlated to leverage, while asset tangibility and retention rate are negatively correlated to leverage. These findings confirm the validity of the pecking order theory. Liquidity and financial distress are negatively correlated to leverage. Consistently with the TO theory, leverage increases with profitability. Share price is positively correlated to leverage and this finding validates the market timing theory. The economic value added (EVA) is positively correlated to leverage and this finding rejects the TO theory. The true speed of adjustment for the sample is $64.20 \%$ for book-todebt ratio and $28.11 \%$ for market-to-debt ratio.
\end{abstract}

Keywords:

Trade-off; Pecking Order; Speed of Adjustment.

+Mr Vusani Moyo is a graduate student from the Department of Financial Management, University of Pretoria, South Africa.

\#Prof Hendrik Wolmarans is an associate professor at the Department of Financial Management, University of Pretoria, South Africa.

+Prof Leon Brümmer is an emeritus professor, Department of Financial Management, University of Pretoria, South Africa. 


\section{INTRODUCTION}

Empirical research on capital structure has identified a number of important firm-specific factors that affect the firm's financing decision. De Angelo and Masulis (1980) showed that, in addition to financial distress costs, non-debt tax shields are important determinants of leverage, as they are perfect substitutes for debt interest tax shields. According to Frank and Goyal (2009) and Huang and Song (2006), the important reliable determinants of leverage are: median industry leverage, market-to-book (firm growth rate) ratio, asset tangibility, profitability, log of assets (firm size) and non-debt tax shields. Frank and Goyal (2003), Mukherjee and Mahakud (2012), Shyam-Sunder and Myers (1999), and Titman and Wessels (1988) have used some of these factors to test for the validity of both the trade-off and pecking order theories. Other researchers, notably Elsas and Florysiak (2011b), Flannery and Rangan (2006), Hovakimian and Li (2010), Hovakimian and Li (2011), and Ramjee and Gwatidzo (2012) have also used some of these factors to estimate the speed of adjustment for firms.

This list, however, excludes the firm's important key financial performance metrics such as the firm's share price, price earnings ratio, earnings retention rate, liquidity, and the more recently developed value measure, the economic value added (EVA). The question that might be asked: What is the relationship between firm leverage and these financial performance metrics? Can these variables be used to estimate the firm's target adjustment speed? This study attempts to provide answers to these questions by developing a partial adjustment model that uses these variables together with some traditional determinants of leverage.

Corporate finance literature has argued that the main objective of financial management is to maximise the wealth of shareholders. This translates into maximising the firm's ordinary share price (Brealey, Myers \& Allen, 2008; Damodaran, 2010). Opler, Saron and Titman (1997) argued that capital structure decisions offer management an opportunity to enhance shareholder value and, as such, define an optimal capital structure as the leverage ratio where shareholder value is maximised. Thus management will seek to attain this objective, and any capital structure that they adopt has to enhance their chances of achieving this primary objective. According to Damodaran (2010), the main pillars of corporate value drivers are the investment, financing and dividend policies, and all of these must be optimised if the share price is to be maximised. The firm's optimal capital structure can therefore be defined in terms of the optimal financing mix that will help management maximise the firm's value. For listed firms, this value translates into a maximum share price for the firm. The share price is a key financial performance metric for listed firms, and it is monitored daily by shareholders, potential investors and other stakeholders. Ideally, management should not falter on the management of this metric.

The main argument of this study is that an optimal capital structure cannot be defined only in terms of weighted average cost of capital (WACC) minimisation or financial slack maximisation, but also in terms of a financial structure that will allow the firm to deliver superior financial performance. Corporate financing is a key component of corporate financial strategy and, as such, it is expected to link with the firm's key financial performance metrics. An optimal capital structure will therefore result in the improved overall financial performance of the firm, thus resulting in the maximisation of all key financial performance indicators, and this will be reflected in the share price growth. At this point, all determinants of capital structure, both quantitative as well as qualitative, will be at a convergence point, and this will define the optimal capital structure of the firm. This optimal capital structure is not static, but rather dynamic, as all variables do change. It also depends on the size and industrial sector of the firm, 
as these factors reflect the levels of operating risks. The key is therefore a dynamic or instantaneous capital structure rather than a static capital structure.

The rest of the paper is structured as follows. Section 2 presents the objectives, scope and limitations of the study and section 3 presents the theoretical background. The research methodology is in section 4 . Section 5 presents the research findings together with the interpretation. The recommendations and areas for future research are presented in section 6 and section 7 presents the conclusion to the study.

\section{OBJECTIVES, SCOPE AND LIMITATIONS}

The objective of the study is to derive and test a model that links leverage with the firm's key financial performance metrics. These metrics are: asset tangibility, financial distress, profitability, cash flow from operations, capital expenditure, economic value added (EVA), ordinary share price, price earnings ratio, earnings retention rate and liquidity. These financial performance metrics are measurable and can be predicted through forecast financial statements; thus the target capital structure that a firm desires will also be predictable. The research further estimates the impact of these variables on the firm's speed of partial adjustment towards target leverage. This study is limited to manufacturing, mining and retail firms listed on the Johannesburg Stock market. The number of firms in each of these sectors is large enough to construct a panel data set that all the chosen estimators can handle with minimum bias. The study excludes listed firms from other sectors as well as unlisted firms from all sectors. The results cannot therefore be generalised to all South African firms. The variables tested used in this study were limited to firm-specific financial performance indicators. The country's macroeconomic variables were excluded. Past research has however demonstrated that these variables are also significant predictors of both leverage and the firm's speed of adjustment.

\section{THEORETICAL BACKGROUND}

\subsection{Firm-specific determinants of capital structure}

These are variables that derive from the firm's uniqueness. Past empirical tests on the trade-off theory have identified the following variables: asset tangibility; profitability; earnings volatility; size; growth rate; financial distress; and dividends and share buybacks as the key determinants of the firm's target leverage ratio. The predictions of the trade-off theory regarding the correlations between leverage and the factors that affect capital structure are presented in TABLE 1. 
TABLE 1: Trade-off Theory: Correlations between Leverage and Capital Structure Determinants (Frank \& Goyal, 2009:26).

\begin{tabular}{ll}
\hline \multicolumn{1}{c}{ Factor } & \multicolumn{1}{c}{ Effect on leverage } \\
\hline ASSET $=$ asset tangibility & Tangibility has a positive effect on leverage \\
SIZE = firm size & Size has a positive effect on leverage \\
\hline FDIST = financial distress & Financial distress has a negative effect on leverage \\
\hline PROF = firm profitability & Profitability has a positive effect on leverage \\
MTB = firm growth rate & Growth rate negative effect on leverage \\
NDTS = non-debt tax shields & NDTS has a negative effect on leverage \\
VOL = volatility & Volatility has a negative effect on leverage \\
\hline
\end{tabular}

Source: Authors'analysis

According to the pecking order theory, the key determinants of firm leverage are: profitability, growth rate, size, capital expenditure, dividends paid, long-term debt repaid, changes in working capital, and cash flow from operations. The predictions of the pecking order theory regarding the correlations between leverage and the factors that affect capital structure are presented in TABLE 2 below

TABLE 2: Pecking Order Theory: Correlations between Leverage and Capital Structure Determinants (Frank \& Goyal, 2003:241; Shyam-Sunder \& Myers, 1999:224).

\begin{tabular}{ll}
\multicolumn{1}{c}{ Factor } & \multicolumn{1}{c}{ Effect on leverage } \\
PROF = firm profitability & Profitability has a negative effect on leverage \\
$M T B=$ firm growth rate & Growth rate positive effect on leverage \\
SIZE = firm size & Size has a positive effect on leverage \\
CAPEX = Capital expenditure & Has a positive effect on leverage \\
DIV +SBB = dividends + share buybacks & Dividends have a positive effect on leverage \\
$R=l o n g$ term debt repaid & Leverage is negatively correlated to R. \\
$\Delta W C=$ changes in working capital & Leverage is negatively correlated to $\Delta W C$ \\
$C F O=$ cash flow from operations & Leverage is negatively correlated to CFO. \\
\hline
\end{tabular}

Source: Authors' analysis

\subsubsection{Asset tangibility}

The stock of the firm's tangible assets is a direct measure of the collateral that the firm can offer to bondholders (Campello \& Giumbona, 2011). Firms with higher stocks of tangibles offer lenders increased security, which in turn increases the firms' debt capacities and lowers their costs of debt (Giambona, Mello \& Riddiough (2009). Thus firms with higher collateral values will find it cheaper and more attractive to borrow. The value of this collateral is further enhanced by 
the liquidity and redeployability of these tangible assets (Morellec, 2001). A higher stock of liquid or re-deployable tangible assets improves a firm's credit score, and this lowers its debt spread. The low spread increases the firm's debt capacity, makes debt finance attractive, and can even facilitate borrowing in periods when credit is tight. The result is that firms with higher stocks of tangible, liquid and redeployable assets are expected to have higher leverage ratios than their counterparts.

\subsubsection{Profitability, size, growth rate, dividends and equity repurchases}

Profitable firms have a greater chance of generating excess "free cash flows", which Jensen (1986:323) defined as 'the residual cash after all financing requirements have been met'. According to Barclay and Smith (2005), profitable firms tend to be large and mature firms with higher stocks of tangibles, and they have limited growth options. These features combine to give these firms a higher credit rating, and this makes borrowing attractive to them. On the other hand, the low growth options reduce the firm's non-debt tax shields, which are perfect substitutes for the interest tax shields. The first problem that these firms face is that of higher corporate taxes which derive from their high profitability. The trade-off theory contends that this problem can be resolved by increasing the firm's debt, which in turn increases the interest tax shield, thus lowering the corporate tax payable. The firm can achieve this by substituting the internal excess equity with debt. The excess internal equity can be returned to the shareholders in the form of dividends and/or share repurchases. The increased debt level ensures that the firm minimises its corporate tax bill while maximising its value through the increased debt interest tax shield. The added benefit of debt in highly profitable firms, according to Harvey, Lins and Roper (2004); Jensen (1986); and Stulz (1990), is that it reduces the agency costs of free cash flow. As debt compels the company to commit cash flows towards interest and capital repayments, it effectively disciplines management and improves their operational efficiencies. The trade-off and agency theories are therefore reconciled on the correlation between leverage and profitability.

In contrast to the trade-off theory, the pecking order theory takes a different view on the role of debt in large, mature and profitable firms. Myers and Majluf (1984) argued that the primary financing objective of all firms is to achieve and maintain financial flexibility. A firm's retention policies play a pivotal role in achieving this objective. They concede that financial flexibility minimises the firm's internal funds deficiency and this reduces its financing frictions. Firms concentrate their financial policies on maximising their financial slacks, which they achieve by adopting sticky dividend polices. The low payout ratio ensures that the firm retains more cash for future financing. The pecking order theory predicts that large, mature and profitable firms have the lowest leverage ratios. The firms will therefore have high cash stockpiles and a high level of unutilised borrowing reserves. The theory predicts that leverage decreases with an increase in the firm's profitability and cash flow from operations.

\subsubsection{Financial distress}

The financial distress ratio is a direct measure of the firm's risk of defaulting on its debt, and this ratio increases with the leverage ratio of the firm. This is one of the building blocks of the trade-off theory of corporate financing. Firms with higher leverage ratios face a higher probability of defaulting on their debt. The financial distress costs are real and they are significant (Cheremushkin, 2011). Several empirical studies, including those of Altman (1984) and Hennessy and Whited (2007), discovered that these costs could be in excess of $20 \%$ of the 
firm's value, but they generally range between $11.0 \%$ and $17.0 \%$. These costs decrease with firm size and increase with leverage. Thus financially distressed firms are expected to rely more on equity financing so as to reduce the agency costs of debt. This argument is plausible to both the trade-off and agency theories. Financially distressed firms are synonymous with financially constrained firms, and they have higher agency costs of underinvestment. To resolve this problem, these firms must issue more equity than debt, making them low-leveraged. The pecking order's financing hierarchy is thus violated. Financially constrained firms cannot borrow to capacity and then issue equity later; such a move would result in extreme costs of equity. The financing choices are limited, with firms finding it difficult to raise either debt or equity (Gilson, 1997).

\subsubsection{The debt interest tax shield and the non-debt tax shields}

The benefits of debt to the issuing firm are not limited only to the lower cost and risk of debt capital as suggested by the pecking order theory. According to the trade-off theory, debt finance also brings with it the interest tax shield, which adds significantly to the overall value of the firm. And according to the agency theory, debt is an effective tool for reducing the agency costs in firms that generate high levels of excess cash flows. These benefits of debt form an integral part of both the trade-off and agency theories of corporate financing. Modigliani and Miller's (1958) capital structure irrelevance and trade-off theories are grounded on the tax benefit of debt to the issuing firm. The debt interest tax shield is a major source of corporate value, and it constitutes the major benefit of debt financing (Opler et al., 1997). Equity dividends do not enjoy similar tax treatments. Thus the tax deductibility of debt interest further discounts the cost of debt finance. This benefit disappears, however, at extreme levels of leverage, as the increasing agency and financial distress costs outweigh the value of the interest tax shield contribution. If tax shields are so valuable, how do the tax theories account for the growing number of zero-leveraged and conservatively leveraged firms? These firms cannot just be destroying value (Strebulaev \& Yang, 2006). The existence of zero-leveraged firms casts doubt on the argument that firms value debt interest tax shields.

The interest rate tax shield is not the only tax shield benefit that accrues to a firm. Firms can also benefit from non-debt tax shields (NDTS) that derive from depreciation, employee share options, foreign tax credits and investment tax credits. De Angelo and Masulis (1980) pointed out that these credits can be perfect substitutes for the debt interest tax shields. According to Graham (2003:1075), a firm's total tax shield is the sum of the interest and non-debt tax shields.

\subsection{The Firm's Additional Key Financial Performance Metrics}

\subsubsection{Economic value added (EVA) and ordinary share price}

The Economic Value Added (EVA) of a firm is derived from its net operating profit after tax (NOPAT), WACC and net assets (NA), and the predictions of the trade-off theory are that the WACC decreases with an increase in leverage up to an optimal leverage point and then increase thereafter. However, firms rarely gear to the optimal level. The EVA decreases with an increasing WACC; it is inversely proportional to the WACC. The EVA is also negatively correlated to leverage.

As share prices $(P)$ rise, the firm is bound to issue more equity, as it can raise more finance than issuing debt; thus leverage declines with an increase in share price. On the other hand, firms with 
declining share prices will find it difficult to convince the market to accept new share offers and hence they will rely on unattractive loans to finance their operations. Leverage is therefore negatively correlated to share price.

\subsubsection{Price earnings ratio $(P / \varepsilon)$}

A firm's price earnings ratio is derived from its share price and earnings per share (EPS). The EPS depends on earnings attributable to equity holders, and the EPS will increase if either earnings attributable to equity holders rise or when the number of outstanding shares decreases. Leverage increases the interest payable thereby decreasing the earnings attributable to equity holders thus reducing EPS. There is a negative correlation between leverage (LEV) and P and the price earnings ratio $(P / \varepsilon)$ ratio.

\subsubsection{Earnings retention rate (RR)}

The Earnings Retention Rate has a direct impact on the cash retained within the firm and hence the firm's internal funds deficits. Profitable firms which retain more of their earnings are likely to suffer agency costs of overinvestment. The trade-off theory predicts that profitable firms with fewer growth options will carry higher debt so as to reduce their taxes and increase their values by the debt interest tax shield. The increased debt substitutes internal equity which is returned to shareholders in the form of dividends and share buybacks. These pay-outs reduce the Earnings Retention Rate while increasing leverage. This implies that Earnings Retention Rate decreases with firm profitability $(R O \varepsilon)$ and leverage (LEV) is negatively correlated to the Earnings Retention Rate (RR).

\subsubsection{Liquidity (LIQ)}

Liquidity is measured by the current ratio, which is defined as current assets divided by current liabilities. The current liabilities include the current portion of borrowings. An increase in borrowings will therefore reduce the firm's liquidity by reducing the current ratio. Leverage (LEV) is therefore negatively correlated to liquidity (LIQ).

\subsection{Target leverage and the speed of adjustment}

The target adjustment tests are discriminatory tests that determine whether firms follow the pecking order or trade-off theory. The speed of adjustment is the differencing factor between the two theories. If the speed of adjustment is zero, then firms have no leverage targets and therefore do not follow the trade-off theory. But in cases where speed of adjustment is greater than zero, then firms have leverage targets that they adjust to, and this supports the trade-off theory - although in its dynamic and not static form (Leary \& Roberts, 2005). In a perfect market, firms will always maintain their target or optimal ratio; but in an imperfect market, firms will only partially adjust, as they face information asymmetries, transaction and adjustment costs. The partial adjustment model is used to estimate the firm's speed of adjustment towards its predetermined target leverage. The speeds of target adjustment will vary between countries, reflecting the differences in these factors. Countries with high-quality firms, good legal systems, favourable institutional features and stable or growing economies will exhibit a higher speed of adjustment. According to Oztekin and Flannery (2012), these characteristics lower adjustment costs and hence facilitate faster and more frequent adjustments. 


\section{METHODOLOGY}

\subsection{Test Hypotheses}

The hypotheses derived from the discussion in section 3 above are:

- $\mathrm{H}_{1}$ : Asset tangibility is positively correlated to leverage.

- $\mathrm{H}_{2}$ : Leverage is negatively correlated to financial distress.

- $\mathrm{H}_{3}$ : Leverage is positively correlated to firm profitability.

- $\mathrm{H}_{4}$ : Leverage is negatively correlated to cash flow from operations.

- $\mathrm{H}_{5}$ : Leverage is positively correlated to capital expenditure.

- $H_{6}$ : $\varepsilon V A$ is negatively correlated to leverage.

- $\mathrm{H}_{7}$ : Leverage is negatively correlated to share price.

- $\mathrm{H}_{8}$ : There is a negative correlation between leverage and the price earnings ratio.

- $\mathrm{H}_{9}$ : Earnings Retention Rate is negatively correlated to leverage.

- $\mathrm{H}_{10}$ : Liquidity is negatively correlated to leverage.

- $\mathrm{H}_{11}$ : Firms have leverage targets that they adjust to at a slow speed.

\subsection{Methodology}

\subsubsection{The Leverage Specification and Partial Adjustment Models}

The study adopts the one-step partial adjustment model used by Flannery and Rangan (2006:472); Hovakimian and Li (2010:4); Hovakimian and Li, (2011:35); and Elsas and Florysiak, (2011b:186). The model is specified as:

$$
L E V_{i, T+1}=\alpha+(\lambda \beta) X_{i, T}+(1-\lambda) L E V_{i, T}+\varepsilon_{i, T+1}
$$

where $L E V_{i, T+1}=$ firm $i$ 's target debt ratio at $T+1$; it is measured by either MDR or BDR; $X_{i, T}=$ a vector of the firm's characteristics; $\beta=$ is coefficient vector and $\lambda=$ speed of adjustment

The firm's target leverage ratio $L E V_{i, T+1}^{*}$ is defined as:

$$
L E V_{i, T+1}^{*}=\hat{\beta} X_{i, T}
$$

This assumes a perfect capital market which implies that firms will always frequently and fully adjust to their target ratio. But in practice, firms face information asymmetries, transaction and adjustment costs; they will therefore infrequently and partially adjust their capital structures towards their leverage ratio. For the trade-off hypothesis to hold, $\beta \neq 0$. Another version of the one-step partial adjustment model that is used by Drobetz and Wanzenried (2006:944) is specified as follows:

$$
L E V_{i, T}=\alpha+(\lambda \beta) X_{i, T}+(1-\lambda) L E V_{i, T-1}+\varepsilon_{i, T}
$$


In theory, the models in equations 1 and 3 should all be equivalent, as they are all dynamic models and should therefore yield the same results. This research also seeks to test for this equivalence. In line with past research, the research uses both BDR and MDR as measures of leverage. The final one-step dynamic models with BDR, MDR and the firm's key financial performance variables are specified as follows:

\section{(Model 1)}

$$
\begin{aligned}
B D R_{i, T+1}=\beta_{0}+ & (1-\lambda) B D R_{i, T}+\lambda \beta_{1} A S S E T_{i, T}+\lambda \beta_{2} F_{D I S T}+\lambda \beta_{3} R R_{i, T}+\lambda \beta_{4} L I Q_{i, T} \\
& +\lambda \beta_{5} E V A_{i, T}+\lambda \beta_{6} P_{i, T}+\lambda \beta_{7} P / E_{i, T}+\lambda \beta_{8} R O E_{i, T}+\lambda \beta_{9} C A P E X_{i, T} \\
& +\lambda \beta_{10} C_{i, T}+\varepsilon_{i, T+1}
\end{aligned}
$$

(Model 2)

$$
\begin{aligned}
B D R_{i, T}=\beta_{0}+(1 & -\lambda) B D R_{i, T-1}+\lambda \beta_{1} A S S E T_{i, T}+\lambda \beta_{2} F D I S T_{i, T}+\lambda \beta_{3} R R_{i, T}+\lambda \beta_{4} L I Q_{i, T} \\
& +\lambda \beta_{5} E V A_{i, T}+\lambda \beta_{6} P_{i, T}+\lambda \beta_{7} P / E_{i, T}+\lambda \beta_{8} R O E_{i, T}+\lambda \beta_{9} C A P E X_{i, T} \\
& +\lambda \beta_{10} C_{i, T}+\varepsilon_{i, T}
\end{aligned}
$$

(Model 3)

$$
\begin{aligned}
M D R_{i, T+1}=\beta_{0}+ & (1-\lambda) M D R_{i, T}+\lambda \beta_{1} A S S E T_{i, T}+\lambda \beta_{2} F D I S T_{i, T}+\lambda \beta_{3} R R_{i, T}+\lambda \beta_{4} L I Q_{i, T} \\
& +\lambda \beta_{5} E V A_{i, T}+\lambda \beta_{6} P_{i, T}+\lambda \beta_{7} P / E_{i, T}+\lambda \beta_{8} R O E_{i, T}+\lambda \beta_{9} C A P E X_{i, T} \\
& +\lambda \beta_{10} C_{i, T}+\varepsilon_{i, T+1}
\end{aligned}
$$

(Model 4)

$$
\begin{aligned}
M D R_{i, T}=\beta_{0}+ & (1-\lambda) M D R_{i, T-1}+\lambda \beta_{1} A S S E T_{i, T}+\lambda \beta_{2} F D I S T_{i, T}+\lambda \beta_{3} R R_{i, T}+\lambda \beta_{4} L I Q_{i, T} \\
& +\lambda \beta_{5} E V A_{i, T}+\lambda \beta_{6} P_{i, T}+\lambda \beta_{7} P / E_{i, T}+\lambda \beta_{8} R O E_{i, T}+\lambda \beta_{9} C A P E X_{i, T} \\
& +\lambda \beta_{10} C_{i, T}+\varepsilon_{i, T}
\end{aligned}
$$

This research used these models to test all the hypotheses listed above.

\subsubsection{Testing Methodology: BDR, MDR and speed of adjustment models}

Models 1 and 3 were the primary models and they were all fitted using the generalised least squares random effects (GLS RE); maximum likelihood random effects (ML RE); fixed effects $(F E)$; Time series (TS); Arellano and Bond (AB); Blundell and Bond (BB) and the Random Effects Tobit (RE Tobit) estimators (with Gauss-Hermite quadrature integration option). Models 2 and 4 were supplementary models that were used in this study to test for the consistency of models 1 and 3 , and they were estimated using only the $(A B)$ and the (BB) estimators. The time series estimator was included to enable the determination of the panel's Durbin-Watson's statistic. The Stata 12 statistical package was used to test all the above models. This is a more suitable package than SAS and Statistical Package for the Social Sciences (SPSS), as it can accommodate all the estimators and it has special options to deal with some statistical errors such as heteroskedasticity.

\subsection{Data sources}

All the financial data used in this research is drawn from the McGregor BFA database's standardised financial statements. The sample consists of 49 manufacturing, 24 mining and 23 retail firms with complete data for four or more consecutive years during 2005 to 2010. 


\section{RESEARCH FINDINGS AND INTERPRETATION}

\subsection{Summary statistics}

The descriptive statistics of the sample are presented in TABL 3 below.

\section{TABLE 3: Sample Statistics}

\begin{tabular}{|c|c|c|c|c|c|}
\hline Variable & Obs. & Mean & SD & Min. & Max. \\
\hline Cash flow from operations (c_t) (R'm) & 607 & $3,068,700$ & $1.36 \mathrm{e}+07$ & $-4,782,000$ & $1.52 e+08$ \\
\hline Capital expenditure (capex) (R'm) & 607 & $2,163,953$ & $9,046,433$ & $-1,314,627$ & $1.06 \mathrm{e}+08$ \\
\hline Asset tangibility (asset) & 607 & 0.314 & 0.237 & 0 & 0.984 \\
\hline Firm size (size) & 607 & 14.40 & 2.19 & 5.95 & 20.12 \\
\hline Firm growth rate (mtb) & 607 & 2.16 & 3.23 & -0.109 & 55.98 \\
\hline Financial distress (fdist) & 562 & 0.803 & 4.68 & -49.16 & 44.76 \\
\hline Liquidity (liq) & 607 & 1.88 & 1.88 & 0 & 25.13 \\
\hline Price earnings ( $p \_e$ ) & 586 & 5.77 & 72.13 & $-1,103.43$ & 468.33 \\
\hline Ordinary share price ( $p)$ (cents) & 588 & $6,215.96$ & 1,2084 & 2 & 110,551 \\
\hline Retention rate (rr) & 607 & 115.31 & 758.64 & -461.03 & $13,459.15$ \\
\hline Firm profitability (roe) & 607 & 51.00 & 579.37 & $-2,550.67$ & $12,555.81$ \\
\hline Economic Value Added (eva) (R'm) & 569 & $182,463.3$ & $5,088,213$ & $-5.00 e+07$ & $6.47 e+07$ \\
\hline Book-to-debt ratio (bdr) & 607 & 0.203 & 0.284 & 0 & 2.28 \\
\hline Market-to-debt ratio (mdr) & 604 & 0.142 & 0.196 & 0 & 1 \\
\hline$\#$ Obs. Market-to-debt ratio $=0$ & \multicolumn{5}{|c|}{$83(13.74 \%)$} \\
\hline \# Obs. Market-to-debt ratio = 1 & \multicolumn{5}{|c|}{$7(1.16 \%)$} \\
\hline \# Obs. Market-to-debt ratio >1 & \multicolumn{5}{|c|}{$0(0.00 \%)$} \\
\hline$\#$ Obs. Book-to-debt ratio $=0$ & \multicolumn{5}{|c|}{$86(14.17 \%)$} \\
\hline$\#$ Obs. Book-to-debt ratio $=1$ & \multicolumn{5}{|c|}{$0(0.00 \%)$} \\
\hline \#0bs. Book-to-debt ratio> 1 & \multicolumn{5}{|c|}{$15(2.47 \%)$} \\
\hline
\end{tabular}

Source: Authors'analysis

The sample consists of 49 manufacturing, 24 mining and 23 retail firms with complete data for two or more consecutive years during the period 2005-2010. There are a total of 449 observations for the period. Extreme outlier observations in all explanatory variables were identified through ridge regression and removed from the sample. The ridge procedure was not used for the dependent variables, bdr and mdr. Variables with VIFs greater than ten were identified and eliminated from the models. 
Cash flow from operations (c_t) (R'm): the cash ex-operations

Capital expenditure (capex) (R'm): the sum of the firm's capital expenditures on fixed assets, new investments and net investments in subsidiaries

Asset tangibility (asset): the fixed assets scaled up by the total assets

Firm size (size): the natural logarithm of total assets

Firm growth rate (mtb): the sum of the market equity, total debt and preferred shares, less deferred taxes; this is scaled up by the total assets

Financial distress (fdist): the De la Rey financial distress ratio

Liquidity (liq): the ratio of total current assets to total current liabilities

Price Earnings Ratio: the firm's year-end share price scaled up by the headlines earnings per share

Ordinary share price $(p)$ (cents): the firm's share price at the end of the financial year

Earnings Retention Rate ( $\mathrm{rr}$ ): the ratio of retained profits to profit attributable to ordinary and preference shareholders

Firm profitability (roe): the profit after taxation scaled up by the total owner's equity

Economic Value Added (EVA) (R'm): the firm's spread multiplied by capital employed

Book-to-debt ratio (bdr): the total debt scaled up by the total assets

Market-to-debt ratio (mdr): the total debt scaled up by the sum of the total debt and firm market capitalisation

\subsection{Correlation results}

The test results of models $1,2,3$ and 4 are contained in TABLES 4 and 5 . The number of observations, $\mathrm{R}^{2}$, WaldChi2, Prob $>\mathrm{Chi}^{2}$ values together with the Durbin-Watson statistics are at the bottom of each table and these confirm that all the models were well-fitted. The Hausman test statistic $\mathrm{Chi}^{2}$ is 57.88 and Prob $>\mathrm{Chi}^{2}$ is .0000 for BDR. The test data set fails to meet asymptotic assumptions of the Hausman test and hence no $p$-value estimate for MDR. This statistic soundly rejects the null hypothesis that the GLS RE estimator is consistent $(p<.05)$ in the case of BDR. It confirms the fixed effects model as a more consistent estimator in the BDR case. The individual effects appear to be correlated with the regressors and the extra orthogonality conditions imposed by the GLS RE estimator are invalid. The results of the GLS RE model were excluded in the determination of the ultimate correlation of each variable. The Hausman test is inapplicable to the other models used in this study. In cases where the estimators give coefficients with different directions, the ultimate correlation is determined by the direction of the majority of the coefficients.

Cash flow from operations: The majority of the coefficients show a weak positive correlation with leverage, which is consistent with the predictions of the trade-off and agency theories. Hypothesis 4 is rejected. These results differ from those of Kayhan and Titman (2007) and Shyam-Sunder and Myers (1999) who found a negative correlation between cash flow from operations and leverage, which is consistent with the pecking order hypothesis. Leverage increases with an increase in cash flow. According to the agency theory, firms with excess cash are likely to suffer agency costs of overinvestment and increased managerial rents, (Jensen, 1986; Stulz, 1990). The managerial rents are normally in the form of higher than market salaries, consumption of perquisites and transfer of assets. The theory argues that this problem can be eliminated by increasing the firm's leverage as debt disciplines management by forcing them to 
commit cash flows to servicing of debt (Harvey et al., 2004; Stulz, 1990). Leverage can be increased by reducing the firm's retention rate. The excess free cash flow is paid out in the form of dividends and share buybacks and this equity portion is then replaced with debt (Harris \& Raviv, 1991).

Capital expenditure: Capital expenditure is positively correlated to both the BDR and the MDR. The results confirm the predictions of the pecking order theory. Hypothesis 5 is thus accepted. For the South African manufacturing, mining and retail firms in this study, leverage increases with an increase in the firm's capital expenditure. This implies that the firms follow the pecking order theory in financing their capital expenditures. As a firm's capital expenditure grows, so does its internal funds deficit. The pecking order theory argues that this deficit is financed in a pecking order, with debt being the first source of external finance chosen (Myers, 1984; Myers \& Majluf, 1984). That is, firms issue debt before considering equity issuances, and this increases their leverage. The argument of the trade-off theory that the firm does not need the interest debt tax shield, as it has the non-debt tax shields deriving from the increased capital expenditure, is thus rejected in this case. Ali Ahmed and Hisham (2009), Kayhan and Titman (2007), and Shyam-Sunder and Myers (1999) found similar correlations between leverage and capital expenditure.

Asset tangibility: Asset tangibility is negatively correlated to both BDR and MDR. The firms' debt levels increase with decreasing asset tangibility. Hypothesis $l$ is rejected. This finding is consistent with the pecking order argument that firms with poor-quality assets voluntarily opt for higher leverage so as to reduce the agency costs resulting from managers consuming perquisites (Bessler, Drobetz \& Kazemieh, 2011). The increased debt levels increase bondholder monitoring costs, as the bondholders effectively monitor managers so as to protect their investments. The trade-off theory predicts a positive correlation, which is rejected in this test. The leverages of the manufacturing, mining and retail firms are inversely proportional to asset tangibility. A number of past empirical studies, notably those by Ali Ahmed and Hisham (2009); Fan, Titman and Twite (2012); Frank and Goyal (2009); and Mukherjee and Mahakud (2012) found similar results.

Liquidity. Leverage is negatively correlated to liquidity, and this confirms hypothesis 10 . The firms' current ratios decrease with an increase in leverage, as additional debt increases a firm's current liabilities, which in turn reduce the overall ratio. In the financial statements, loan liabilities are split into current and non-current liabilities. The current portion of the loan is included in the total current liabilities when calculating the firm's current ratio. Therefore, an increase in the current portion of loans decreases the firm's current ratio, and hence there is an inverse relationship between leverage and liquidity. Dawood, Moustafa and El-Hennawi (2011) and Mahakud and Mukherjee (2011) documented similar results.

Financial distress: There is a significant negative correlation between financial distress and the firm's leverage, and financial distress is a significant predictor of both the BDR and the MDR in the full sample. These results confirm the validity of both theories, and hypothesis 2 is thus accepted. Leverage decreases with an increase in financial distress. Distressed firms find it difficult to attract debt finance, as investors are unwilling to extend more credit, due to the increased default risk (Gilson, 1997). This decreases the firm's debt capacity while increasing the cost of borrowing. Distressed firms therefore rely more on equity financing, and hence the inverse relationship between financial distress and leverage.

Firm profitability. Profitability is positively correlated to firm leverage. It is a significant predictor of the MDR. The positive correlation implies that the firms' leverages increase with an 
increase in firm profitability. This financing behaviour is consistent with the trade-off theory hypothesis. These results therefore confirm the validity of the trade-off theory in the full sample, and hypothesis 3 is thus accepted. The leverages of the manufacturing, mining and retail firms increase with an increase in profitability, implying that profitable firms use more debt. According to the trade-off theory, profitable firms face increased tax payable, and they can reduce this through the use of debt interest tax shields or non-debt tax shields (Shivdasani \& Zenner, 2005). In the absence of non-debt tax shields, firms use interest tax shields, as the two are perfect substitutes (De Angelo and Masulis, 1980). The results imply that the firms use debt interest tax shields to reduce their tax bills. The firms must therefore increase their leverage in order to optimise their debt interest tax shields. The trade-off theory further confirms that tax shields add a significant amount of value to a firm's overall value. Surprisingly, a number of studies have found negative correlations between leverage and profitability. Studies by Fan et al., (2012); Frank and Goyal (2009); Kayhan and Titman (2007); and Mukherjee and Mahakud (2012) found that profitability is negatively correlated to leverage, implying that European and US firms tend to follow the pecking order theory.

Price earnings: The results of all the models confirm a negative correlation with both BDR and MDR. Most of the correlation coefficients are insignificant, however. This correlation is consistent with hypothesis 8 and hence it is accepted. The firm's earnings per share, which is a key measure of shareholder return, decreases with an increase in firm leverage. An increase in the stock of debt increases the firm's interest payable and this reduces the earnings attributable to shareholders, thereby reducing the earnings per share. This implies that goodquality firms use less debt so as to maximise their earnings per share. These results contradict the prediction of the signalling theory. According to the signalling theory, good quality firms signal their prospects by increasing their leverage, and thus the share price increases as investors read this signal (Miglo, 2011). The higher share price increases the firm's P/E. That is, according to the signalling theory, price earnings increase with an increase in the firm's leverage. In the full sample of manufacturing, mining and retail firms, leverage is inversely proportional to price earnings.

Ordinary share price: A majority of the estimators predict a negative correlation with leverage. It is also a significant predictor of leverage. The results confirm hypothesis 7 . The leverages of the firms decrease with an increase in the share price and this is consistent with the predictions of the market timing theory. According to this theory, firms facing high share returns tend to rely more on equity financing than debt (Alti \& Sulaeman, 2012; Baker \& Wurgler, 2002; Hovakimian, Hovakimian \& Tehranian, 2004). It is beneficial for firms to issue equity when share prices are high, as this increases the net cash proceeds. Furthermore, rising share prices indicate good prospects for the firm. Firms facing poor share returns are expected to rely more on debt finance, as they would find it difficult to convince the market to accept new share offers. The results of this study reject the predictions of the signalling theory.

Retention rate: Retention rate is negatively correlated to leverage. Firms with higher retention rates use less debt. This is consistent with the pecking order theory and hypothesis 9 is accepted. According to the pecking order theory, firms rely on internal funds for their capital expenditures. They consider outside finance only when faced with an internal funds deficit. Leverage is therefore a function of internal funds deficits (Shyam-Sunder \& Myers, 1999). An increased internal funds deficit leads to an increase in leverage, as firms tend to finance their deficits in a pecking order, with debt finance being the first choice (Myers, 2008). 
Economic value added: EVA is positively correlated to leverage, and this rejects the validity of the trade-off theory. Hypothesis 6 is therefore rejected. The EVA of the sample firms increases with increasing leverage. This relationship cannot be explained by the trade-off theory. The results imply that WACC increases with leverage resulting in EVA decreasing with increasing leverage. The trade-off theory's predictions are rejected in this case.

The most significant determinants of leverage in the sample firms are liquidity, capital expenditure, ordinary share price and financial distress. The correlation results for cash flow are consistent with both the trade-off and agency theories, while the price earnings results contradict the signalling theory. The correlations on share price confirm the validity of the market timing theory and reject the signalling theory hypothesis. The retention rate correlation results confirm the pecking order theory. The EVA correlation results reject the trade-off theory hypothesis. An analysis of these results indicates that the correlation results largely depend on the dependent variable used, the model fitted and the estimator chosen.

\section{TABLE 4: BDR Regression Output and Speeds of Adjustment of Manufacturing, Mining and Retail Firms}

Regression results for the partial adjustment model 1: $B D R_{i, T+1}=\alpha+(\lambda \beta) X_{i, T}+(1-\lambda) B D R_{i, T}+c_{i, T}+$ $\varepsilon_{i, T+1} \ldots \ldots$. [Model 1] and model 2: $B D R_{i, T}=\alpha+(\lambda \beta) X_{i, T}+(1-\lambda) B D R_{i, T-1}+\varepsilon_{i, T} \ldots \ldots$ [Model 2]

Where $\lambda$ is the adjustment speed on the lagged book-to-debt ratio (BDR), $c_{i, T}$ is the time-invariant unobserved variable (firm fixed effect) and $\varepsilon_{i, T+1}$ is an error term.

The key financial performance variables determining the firm's long-run target leverage and the speed of adjustment are defined in TABLE 3 . T-statistics are reported in parentheses.

The markings $* \star \star, \star \star$ and $*$ on coefficient estimates denote significant differences from zero at the levels of $1 \%$, $5 \%$, and $10 \%$ respectively. The implied half-life is calculated as: half - life $=\log (0.5) / \log (1-\lambda)$.

Model specifications are shown at the bottom of the table. In the ML Random effects model, the Wald Chi 2 statistics are replaced by LR Chi 2 , and in both the fixed effects and time series models, they are replaced by $F$.

Model 2 is estimated using only the Arellano \& Bond estimator and the Blundell \& Bond estimator. The Hausman test statistic Chi2 is 57.88 and Prob > Chi2 is 0.0000.

\section{TABLE 5: MDR regression output and speeds of adjustment for manufacturing, mining and retail firms}

Regression results for the partial adjustment model 3: $M D R_{i, T+1}=\alpha+(\lambda \beta) X_{i, T}+(1-\lambda) M D R_{i, T}+c_{i, T}+$ $\varepsilon_{i, T+1} \ldots \ldots$ [Model 3] and model 4: $M D R_{i, T}=\alpha+(\lambda \beta) X_{i, T}+(1-\lambda) M D R_{i, T-1}+\varepsilon_{i, T} \ldots \ldots[$ [Model 4]

Where $\lambda$ is the adjustment speed on the lagged market-to-debt ratio (MDR), $c_{i, T}$ is the time-invariant unobserved variable (firm fixed effect) and $\varepsilon_{i, T+1}$ is an error term.

The key financial performance variables determining the firm's long-run target leverage and the speed of adjustment are defined in TABLE 3. T-statistics are reported in parentheses.

The markings $* \star \star, * \star$ and $*$ on coefficient estimates denote significant differences from zero at the levels of $1 \%$, $5 \%$, and $10 \%$ respectively. The implied half-life is calculated as: half - life $=\log (0.5) / \log (1-\lambda)$.

Model specifications are shown at the bottom of the table. In the ML Random effects model, the Wald Chi 2 statistics are replaced by LR Chi 2 , and in both the fixed effects and time series models, they are replaced by $F$.

Model 9 is only estimated using the Arellano \& Bond estimator and the Blundell \& Bond estimator. The Hausman test statistic Chi2 is -8.20 and Prob>Chi2 (data fails to meet asymptotic assumptions of Hausman test). 


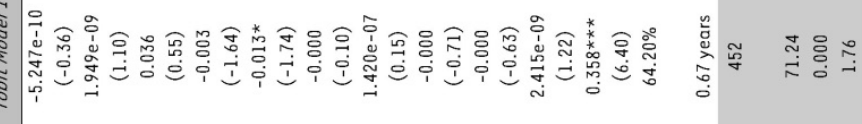

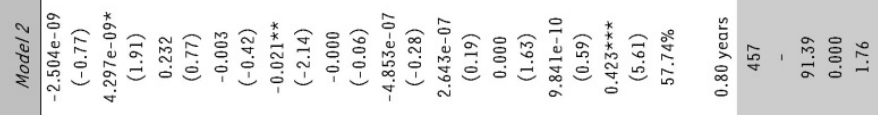

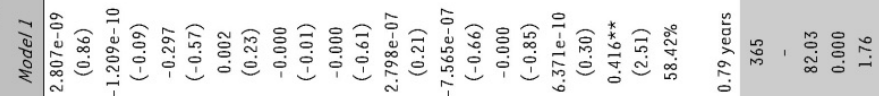

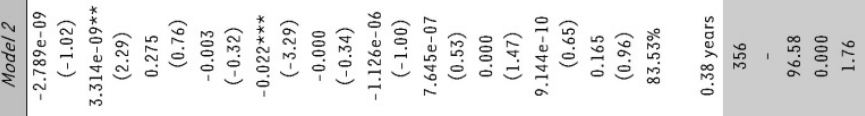

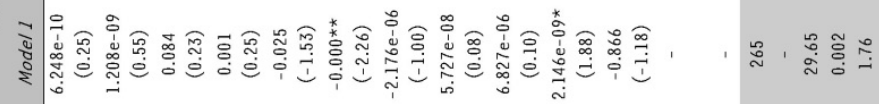

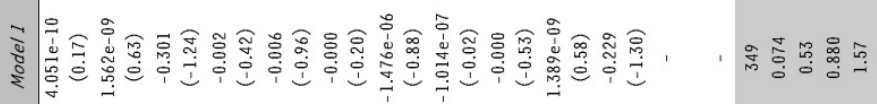

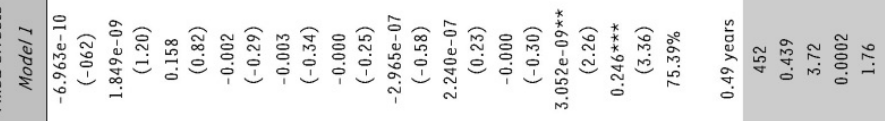

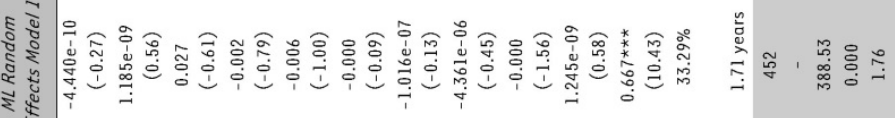

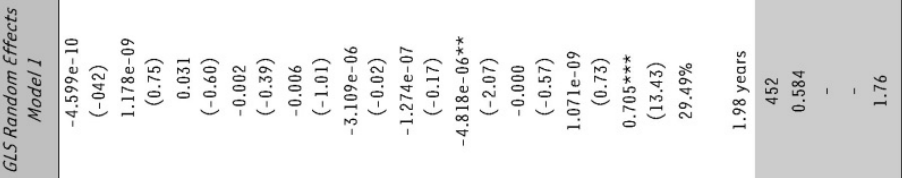

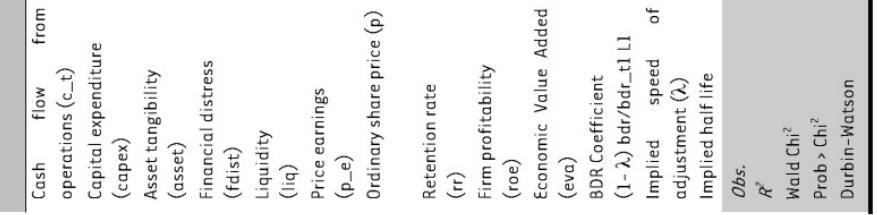




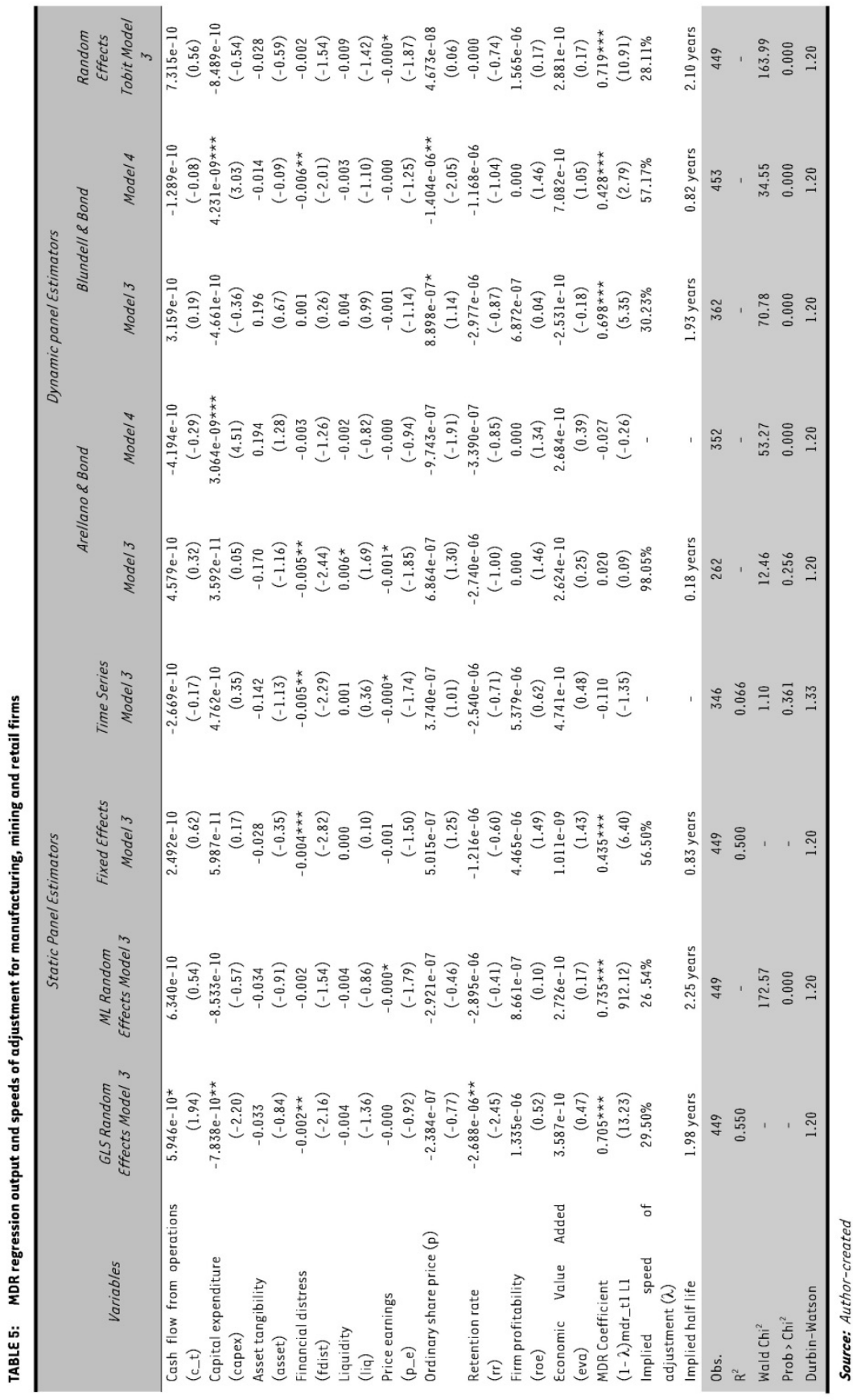




\subsection{Speed of adjustment results}

The ML RE, FE, BB and the RE Tobit estimators give positive and significant coefficients for the lagged BDR and MDR variables. This indicates that firms have target leverages towards which they adjust over time. The TS and AB estimators all failed to estimate the speed of adjustment for all the models. The average speed of adjustment in models 1 and 2 is $57.81 \%$ ( 0.90 years). On average, it takes 0.90 years for the firms to fully adjust to their desired targets, provided they maintain the same adjustment speed. The speeds of adjustment lie between $33.29 \%$ ( 1.71 years) and $75.39 \%$ ( 0.49 years). The mean speed of adjustment for models 3 and 4 is $39.71 \%$ ( 1.58 years). The speeds of target adjustment of models 3 and 4 lie between $26.54 \%$ (2.25 years) and $57.17 \%$ ( 0.82 years). The true speed of adjustment is estimated as $64.20 \%$ for BDR and $28.11 \%$ for MDR. The BDR estimate is in line with the estimates of $65.5 \%$ (for total debt ratio (TDR)) and $80.2 \%$ (for long-term debt ratio (LTR)) provided by Ramjee and Gwatidzo (2012), but the MDR estimate is much lower than these estimates. The MDR estimate is much closer to the $26.3 \%$ estimates of Elsas and Florysiak (2011a). The results however indicate a higher speed of adjustment than that of their US and European firms obtained in previous studies. Studies on both US and European firms show target adjustment speeds of $8.00 \%$ (Kayhan \& Titman, 2007), $36.00 \%$ (Flannery \& Rangan, 2006), 32.00\% (Antoniou, Guney \& Paudyal, 2008) and 5.5-7.4\% (Hovakimian \& Li, 2011). The higher speeds for South African firms indicate frequent capital structure adjustment, which may be motivated by lower adjustment costs.

Finally, the results indicate that the speed of adjustment depends on the dependent variable used (BDR or MDR), the estimator used and the model fitted. The speeds are generally higher for BDR models than for MDR models.

\section{RECOMMENDATIONS AND AREAS FOR FUTURE RESEARCH}

This study focused only on manufacturing, mining and retail firms listed on the Johannesburg Stock Exchange. It specifically excluded listed firms from other sectors and unlisted firms. Future research can extend this study to cover the excluded sectors and unlisted firms as well. This research used only firm-specific variables to determine the speed of target adjustment. It is further recommended that future research on South African firms should extend the list of variables to include the macroeconomic variables in the determination of the speed of target adjustment.

\section{CONCLUSION}

This study investigates the relationship between leverage and the firms' key financial performance variables for the South African manufacturing, mining and retail firms listed on the Johannesburg Stock Exchange. The study further examines the impact of these variables on the firms' target speed of adjustment. The study documents that the most significant firm-specific determinates of firm leverage are liquidity, capital expenditure, ordinary share price and financial distress.

- Leverage increases with cash flow, and this is consistent with the predictions of the trade-off and agency theories. 
- Capital expenditure is positively correlated to both BDR and MDR. The results confirm predictions of the pecking order theory.

- Asset tangibility is negatively correlated to both BDR and MDR. This correlation confirms the pecking order hypothesis while rejecting the trade-off hypothesis.

- Leverage decreases with firm liquidity.

- There is a significant negative correlation between financial distress and the firm's leverage and it is a significant predictor of both BDR and MDR.

- Consistently with the trade-off theory, leverage increases with profitability.

- Retention rate is negatively correlated to leverage. Firms with higher retention rates use less debt. This is consistent with the pecking order theory.

- EVA is positively correlated to leverage and this rejects the validity of the trade-off theory.

These variables have an impact on the firms' speed of adjustment towards target leverage. The speeds are generally higher for BDR models than the MDR models. The true speed of adjustment for the sample is $64.20 \%$ ( 0.67 years) for BDR and $28.11 \%$ (2.10 years) for MDR. The correlation and speed of adjustment results depend on the dependable variable used (BDR or MDR); the estimator used and the model fitted.

\section{LIST OF REFERENCES}

Ali Ahmed, H.J. \& Hisham, N. (2009). Revisiting capital structure theory: a test of pecking order and static order trade-off model from Malaysian capital market. International Research Journal of Finance and Economics, 30, pp. 58-65.

Alti, A. \& Sulaeman, J. (2012). When do high stock returns trigger equity issues? Journal of Financial Economics, 103(1), pp. 61-87.

Altman, $\varepsilon$. (1984). A further empirical investigation of the bankruptcy cost question. The Journal of Finance, 39(4), pp. 1067-1089.

Antoniou, A., Guney, Y. \& Paudyal, K. (2008). The determinants of capital structure: capital market oriented versus bank oriented institutions. Journal of Financial and Quantitative Analysis, 43(1), pp. 59-92.

Baker, M. \& Wurgler, J. (2002). Market timing and capital structure. The Journal of Finance, 57(1), pp. $1-32$.

Barclay, M.J. \& Smith, C.W. (2005). The capital structure puzzle: the evidence revisited. Journal of Applied Corporate Finance, 17(1), pp. 8-17.

Bessler, W., Drobetz, W. \& Kazemieh, R. (2011). Factors affecting capital structure decisions. In: Baker, H.K \& Martin, G.S. (eds.) Capital structure and corporate financing decisions: theory, evidence, and practice. New Jersey: John Wiley.

Brealey, R.A., Myers, S.C. \& Allen, F. (2008). Principles of corporate finance, $9^{\text {th }}$ ed. New York: McGrawHill.

Campello, M. \& Giambona, દ. (2011). Capital structure and the redeployability of tangible assets.

Working Paper, 1-39. [Online] Available:

http://papers.ssrn.com/sol3/papers.cfm?abstract_id=1562523. (Accessed 10 December 2011) 
Cheremushkin, S.V. (2011). Capital structure irrelevance: the Modigliani-Miller theorem. In: Baker, H.K. \& Martin, G.S. (eds.) Capital structure and corporate financing decisions: theory, evidence, and practice. New Jersey: John Wiley.

Dawood, M.H.A.K., Moustafa, E.I. \& El-Hennawi, M. (2011). The determinants of capital structure in listed Egyptian corporations. Middle Eastern Finance and Economics, 9, pp. 83-99.

Damodaran, A. (2010). Corporate finance, B40.2302; Lecture Notes Packet 1. [Online] Available: http://pages.stern.nyu.edu/ adamodar/. (Accessed 10 December 2011)

De Angelo, H. \& Masulis, R.W. (1980). Optimal capital structure under corporate and personal taxation. Journal of Financial Economics, 8(1), pp. 3-39.

Drobetz, W. \& Wanzenried, G. (2006). What determines the speed of adjustment to the target capital structure? Applied Financial Economics, 16(13), pp. 941-958.

Elsas, R. \& Florysiak, D. (201la). Dynamic capital structure adjustment and the impact of fractional dependent variables. Working Paper, Institute of Finance and Banking, University of Munich, 1-44. [Online] Available: http://papers.ssrn.com/sol3/papers.cfm?abstract_id=1632362. (Accessed 10 December 2011)

Elsas, R. \& Florysiak, D. (2011b). Heterogeneity in the speed of adjustment toward target leverage. International Review of Finance, 11 (2), pp. 181-211.

Fan, J.P.H., Titman, S. \& Twite, G. (2012). An international comparison of capital structure and debt maturity choices. Journal of Financial and Quantitative Analysis, 47 (1), pp. 23-56.

Flannery, M. \& Rangan, K. (2006). Partial adjustment toward target capital structures. Journal of Financial Economics, 79(3), pp. 469-506.

Frank, M.Z. \& Goyal, V.K. (2003). Testing the pecking order theory of capital structure. Journal of Financial Economics, 67(2), pp. 217-248.

Frank, M.Z. \& Goyal, V.K. (2009). Capital structure decisions: which factors are reliably important? Financial Management, 38(1), pp. 1-37.

Giambona, E., Mello, A. \& Riddiough, T. (2009). Collateral and debt capacity in the optimal capital structure. Working Paper, 1-48. [Online] Available:

http://www.reri.org/research/article_pdf/wp169.pdf. (Accessed 10 December 2011)

Gilson, S.C. (1997). Transaction costs and capital structure choice: evidence from financially distressed firms. The Journal of Finance, 52(1), pp. 161-196.

Graham, J.R. (2003). Taxes and corporate finance: a review. The Review of Financial Studies, 16 (4), pp. 1075-1129.

Harris, M \& Raviv, A. (1991). The theory of capital structure. The Journal of Finance, 46(1), pp. $297-$ 355.

Harvey, C.R., Lins, K.V. \& Roper, A.H. (2004). The effect of capital structure when expected agency costs are extreme. The Journal of Financial Economics, 74(1), pp. 3-30.

Hennessy, C.A. \& Whited, T.M. (2007). How costly is external financing? Evidence from a structural estimation. The Journal of Finance, 62(4), pp. 1705-1745.

Hovakimian, A., Hovakimian, G. \& Tehranian, H. (2004). Determinants of target capital structure: the case of dual debt and equity issues. Journal of Financial Economics, 71(3), pp. 517-540. 
Hovakimian, A. \& Li, G. (2010). Is the partial adjustment model a useful tool for capital structure research? Review of Finance, pp. 1-22. [Online] Available:

http://rof.oxfordjournals.org/content/early/2010/09/08/rof.rfq020.full.pdf+html. (Accessed 10 December 2011)

Hovakimian, A. \& Li, G. (2011). In search of conclusive evidence: how to test for adjustment to target capital structure. Journal of Corporate Finance, 17(1), pp. 33-44.

Huang, G. \& Song, F.M. (2006). The determinants of capital structure: evidence from China. China Economic Review, 17(1), pp. 14-36.

Jensen, M.C. (1986). Agency cost of free cash flow, corporate finance and takeovers. The American Economic Review, 76(2), pp. 323-329.

Kayhan, A. and Titman, S. (2007). Firm histories and their capital structures. Journal of Financial Economics, 83(1), pp. 1-32.

Leary, M.T. \& Roberts, M.R. (2005). Do firms rebalance their capital structures? The Journal of Finance, 60(6), pp. 2575-2619.

Mahakud, J. \& Mukherjee, S. (2012). Determinants of adjustment speed to target capital structure: evidence from Indian manufacturing firms. International Conference on Economics and Finance Research, IPEDR (4), pp. 67-71.

Miglo, A. (2011). Trade-off, pecking order, signalling, and market timing models. In: Baker, H.K. \& Martin, G.S. (eds.) Capital structure and corporate financing decisions: theory, evidence, and practice. New Jersey: John Wiley.

Morellec, $\varepsilon$. (2001). Asset liquidity, capital structure, and secured debt. Journal of Financial Economics, 61(2), pp. 173-206.

Mukherjee, S. \& Mahakud, J. (2012). Are trade-off and pecking order theories of capital structure mutually exclusive? Evidence from Indian manufacturing firms. Journal of Management Research, 12(1), pp. 41-55.

Myers, S.C. (1984). The capital structure puzzle. The Journal of Finance, 39(3), pp. 575-592.

Myers, S.C. \& Majluf, N.S. (1984). Corporate financing and investment decisions when firms have information that investors do not. Journal of Financial Economics, 13(2), pp. 187-221.

Opler, T.C., Saron, M. \& Titman, S. (1997). Designing capital structure to create shareholder value. Journal of Applied Corporate Finance, 10(1), pp. 21-31.

Oztekin, 0. \& Flannery, M.J. (2012). Institutional determinants of capital structure adjustment speeds. Journal of Financial Economics, 103(1), pp. 88-112.

Ramjee, A. and Gwatidzo, T. (2012). Dynamics in capital structure determinants in South Africa. Meditari Accountancy Research, 20(1), pp. 52-67.

Shivdasani, A. \& Zenner, M. (2005). How to choose a capital structure: navigating the debt-equity decision. Journal of Applied Corporate Finance, 17(1), pp. 26-35.

Shyam-Sunder, L. \& Myers, S.C. (1999). Testing static trade-off against pecking order models of capital structure. Journal of Financial Economics, 51(2), pp. 219-244.

Strebulaev, I.A. \& Yang, B. (2006). The mystery of zero-leverage firms. Working Paper, Graduate School of Business, Stanford University. [Online] Available: http://papers.ssrn.com/sol3/papers.cfm?abstract_id=890719. (Accessed 10 December 2011) 
Stulz, R.M. (1990). Managerial discretion and optimal financing policies. Journal of Financial Economics, 26(1), pp. 3-27.

Titman, S. \& Wessels, R. (1988). The determinants of capital structure choice. The Journal of Finance, 43(1), pp. 1-19. 
Moyo, Wolmarans \& Brümmer 